Науковий вісник НЛтУ України
Scientific Bulletin of UNFU
https://nv.nltu.edu.ua
$\begin{gathered}\text { https://doi.org/10.15421/40280702 } \\ \text { Article received 17.07.2018 p. } \\ \text { Article accepted 26.09.2018 p. } \\ \text { Удк 630*22 }\end{gathered}$

Ю. С. Шпарик, Р. М. Вітер, В. Ю. Шпарик

Прикарпатський національний університет ім. Василя Стефаника, м. Івано-Франківськ, Україна

\title{
ВПЛИВ ПРИРОДНИХ ФАКТОРІВ НА ДИНАМІКУ БУКОВОГО (FAGUS SYLVATICA L.) ПРАЛІСУ УКРАЇНСЬКИХ КАРПАТ
}

\begin{abstract}
Міжнародні дослідження 15-річної динаміки букового пралісу проведено на 10-гектарному стаціонарному дослідному об'єкті в Угольському масиві Карпатського біосферного заповідника. Проаналізовано вплив вітровалу 2007 р. та потепління клімату на структурні елементи екосистеми пралісу. Виявлено достовірні зміни окремих показників пралісу внаслідок сильного впливу вітру: найбільші коливання характерні для густоти дерев - після втрати 10 \% (у 2007 р.) вже в 2010 р. густота збільшилася на 6, а в 2015 р. - на 59 \%; істотно зріс і запас мертвої деревини (відповідно на 41 та 6 \%); відносне зменшення найбільшим було для кількості підросту (на 19 та $14 \%$ ); зменшення запасу деревини було вже меншим (на 7 і 4 \%); зменшення суми площ поперечного перетину було неістотним (на 4 і 2 \%). Аналіз реакції букового пралісу на сильний вплив вітру підтверджує гіпотезу про максимальну стійкість таких лісових екосистем до стихійних явищ, а ідентифіковані кількісні зміни дали змогу розробити принципову схему сильного впливу вітру на праліс. Дискусійним залишається питання збільшення приросту за діаметром під впливом потепління клімату - у 2010 і в 2015 рр. воно було достовірним для більшості ступенів товщини, але на його динаміку вплинув також і вітровал через зрідження намету.
\end{abstract}

Ключові слова: вітровал; деревостан; густота дерев; запас деревини; мертва деревина; підріст; приріст деревини; потепління клімату.

Вступ. Сучасний стан лісів Українських Карпат, зокрема масове всихання лісів регіону та низька ефективність використання лісорослинного потенціалу грунтів, знову спонукають до розгляду механізмів самопідтримання життєвості лісів, які, з одного боку, забезпечують стале надходження коштів у процесі ведення лісового господарства, а 3 іншого - дають змогу формувати деревостани цільової структури та породного складу (Stojko, 2006; Hobi et al., 2015; Shparyk, 2016; Didukh et al., 2016). Праліси є природними лісовими екосистемами, які існують вже багато століть завдяки тому, що в них ці механізми успішно працюють. Праліси здатні нівелювати природні загрози, наприклад вітровали, завдяки складній структурі деревостану. Багато вчених наголошують, що саме підріст є одним 3 основних елементів стійкості лісів, оскільки навіть в разі втрати основного намету деревостану він в змозі зберегти лісове середовище та з часом відновити лісову екосистему (Korpel, 1995; Shparyk et al., 2010; Commarmot et al., 2013; Lavnyy \& Zajats, 2013). Тому для лісівництва важливим є розуміння механізму, який забезпечує довготривале і стабільне функціонування лісових екосистем. Наукова література свідчить, що найбільш поширеними та руйнівними для лісів стихійними явищами в Українських Карпатах є вітровали (Kalutskyj \& Olijnyk, 2007). Згідно 3 класифікацією (Shparyk \& Viter, 2012) виділяють такий вплив вітру на ліс: незначний - не має негативних наслідків; слабкий - ламає сухостій; сильний - валить живі дерева; катастрофічний - повністю руйнує деревостан. Вітровал 2007 р. в Угольському масиві букових пралісів мав сильний вплив.

Методика дослідження. Об'єктом дослідження були 10 га букового (Fagus sylvatica L.) пралісу у кварталі 2 Угольського відділення Карпатського біосферного заповідника. Цю територію (200 на 500 м) було розділено на сорок $(50 \times 50$ м $=0,25$ га) постійних пробних площ i на кожній проведено чотири інвентаризації і картування живих дерев, товстіших за $6 \mathrm{~cm}$, лежачої деревини та підросту в 2000, 2005, 2010 та 2015 рр. Дерева заміряли 3 діаметра 6 см (на висоті 1,3 м), а колоди мертвої деревини - 3 діаметра в тонкому кінці понад 8 см та 3 довжини понад 2 м. Інвентаризацію природного відновлення (підріст вище $10 \mathrm{~cm}$ і тонше $6 \mathrm{~cm}$ на висоті $1,3 \mathrm{~m}$ ) кожної інвентаризації реалізовували на 160 постійних кругових площадках (кожна площею $20 \mathrm{~m}^{2}$ ), тобто на $3,2 \%$ площі. За даними польових робіт сформовано електронні таблиці (деревостан, мертва лежача деревина, підріст) в середовищі MS Excel, де і виконано всі розрахунки.

Результати дослідження та їх обговорення. Якщо результати попередніх інвентаризацій дали підставу висунути тезу про незначну мінливість основних показників пралісових екосистем (Shparyk, 2010), то четверта інвентаризація 2015 р. свідчить, що ця теза не зовсім

Інформація про авторів:

Шпарик Юрій Степанович, д-р с.-г. наук, ст. наук. співробітник, доцент, кафедра лісознавства. Email: уuriy.shparyk@рu.if.ua Вітер Роман Михайлович, канд. с.-г. наук, доцент, кафедра лісознавства. Email: roman.viter@pu.if.ua

Шпарик Віктор Юрійович, канд. біол. наук, викладач, кафедра біології та екологіï. Email: viktor.shparyk@pu.if.ua

Цитування за ДСтУ: Шпарик Ю. С., Вітер Р. М., Шпарик В. Ю. Вплив природних факторів на динаміку букового (Fagus sylvatica L.) пралісу Українських карпат. Науковий вісник НЛтУ України. 2018, т. 28, № 7. С. 13-16.

Citation APA: Shparyk, Yu. S., Viter, R. M., \& Shparyk, V. Yu. (2018). Influence of natural factors on the dynamics of the beech (Fagus sylvatica L.) virgin forest of the Ukrainian carpathians. Scientific Bulletin of UNFU, 28(7), 13-16. https://doi.org/10.15421/40280702 
правильна. Так, якщо густота дерев букового пралісу (без сухостою) за перших 10 років спостережень коливалася близько 280 шт. на 1 га в межах $5 \%$, то з 2010 по 2015 pр. вона зросла одразу на $50 \%$ і становила понад 445 шт. га $^{-1}$. У розрізі порід динаміка подібна - незначні коливання 32000 по 2010 pp. і різке збільшення до 2015 р., але інтенсивність цього зростання різна: букна $34 \%$, ясен - на 45, клен гостролистий - на 220, явір - на 603, ільм - на 453 \%. Окрім цього, одразу чотири нові породи (дуб скельний, черешня, горобина та верба козяча) з'явилися в буковому пралісі. Це дає підставу констатувати, що причинами змін густоти дерев та породного складу пралісу з 2005 по 2015 рр. були природні умови: вітровал 2007 р. і збільшення суми активних температур (за даними Угольського ПНДВ - на $50 \%)$.

Динаміка суми площ поперечного перетину (абсолютної повноти) живих дерев букового пралісу, порівняно 3 його густотою, була іншою - коливання цього показника навколо $39 \mathrm{~m}^{2} \cdot \mathrm{ra}^{-1}$ не перевищували $5 \%$ за період 2000-2015 pp. 3 мінімумом у 2010 р. $37,54 \mathrm{~m}^{2} \cdot \mathrm{ra}^{-1}$. Запас деревини живих дерев букового пралісу має істотні зміни за період спостережень, як і кількість дерев. Тільки якщо густота пралісу мала тенденцію до збільшення, то запас до зменшення - від 617 до $587 \mathrm{~m}^{3} \cdot \mathrm{ra}^{-1}$. За перші 5 років були тільки незначні зміни запасу в окремих порід. За наступні 5 років зменшився запас пралісу на $45,1 \mathrm{~m}^{3} \cdot \mathrm{ra}^{-1}$ (7\%) внаслідок вітровалу 2007 р. Зазначимо, що розрахунки на 2008 р. свідчать про втрати запасу внаслідок вітровалу на рівні $10 \%$ (понад $60 \mathrm{~m}^{3} \cdot \mathrm{ra}^{-1}$ ). 32010 по $2015 \mathrm{pp}$. запас зріс майже на $3 \%$. За породами описана динаміка запасу деревини букового пралісу характерна лише для бука, а щодо інших, то: запас клена коливається близько $15 \mathrm{~m}^{3} \cdot \mathrm{ra}^{-1}$, хоча i має незначну тенденцію до зростання (після 2005 р.); запас ясена має динаміку до зменшення, особливо після 2005 р.; запаси явора та ільма мають тренд до зростання за весь період спостережень (відповідно на 64 і $43 \%$ ) (рис. 1).

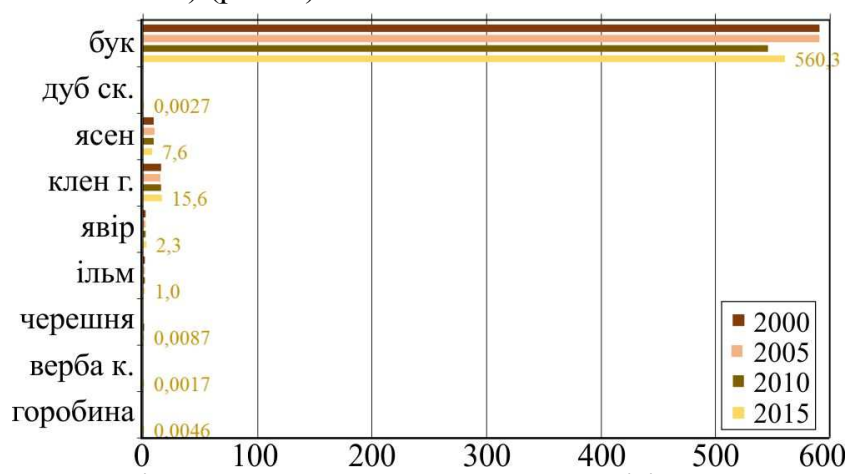

Рис. 1. Зміни запасу деревини в буковому пралісі за породами

Розподіл дерев за діаметром у буковому пралісі за 15 років спостережень постійно змінюється, але тип цього розподілу залишається спадним, тобто характерним для різновікових деревостанів. I якщо в 2005 р. зміни кількості дерев за ступенями товщини коливалися в межах $\pm 25 \%$, то в 2010 р. (після вітровалу) величина цих коливань зросла до $\pm 50 \%$. Найбільші кількісні зміни в 2015 р. порівняно з 2010 р. відбулися на найтонших ступенях товщини - густота дерев пралісу збільшилася на 8-сантиметровому ступені на $138 \%$ (від 93 до 220 шт. га $^{-1}$ ), на 12 см - на 88, на 16 см - на 91, на $20 \mathrm{~cm}$ - на 50, на 24 см - на 30 і на $28 \mathrm{~cm}$ - на $51 \%$. На більшості середніх (від 32 до 84 см) ступенів товщини кількість дерев навпаки зменшилася до $47 \%$, тобто саме дерев середнього діаметра було повалено вітровалом найбільше. Зміни на найтовстіших (від 88 до 132 см) ступенях найбільші у відсотковому вимірі, але не мають однієї закономірності - вони можуть бути як більшими на $400 \%$ (на 116 см ступені товщини), так і меншими на $100 \%$ (на 124 і 132 см ступенях товщини), що пояснюють малою кількістю дерев на цих ступенях.

Зміни запасу деревини за ступенями товщини дають підставу стверджувати, що найбільші втрати запасу після вітровалу 2007 р. відбулися на середніх ступенях товщини, зокрема на $76 \mathrm{~cm}-13,4 \mathrm{~m}^{3}$ та $80 \mathrm{~cm}-11,0 \mathrm{~m}^{3}$, що у відсотковому вимірі становило відповідно 24 та $18 \%$ (рис. 2). Лише трохи менші втрати на ступенях товщини 60 (9,3 м або $24 \%)$ та 52 см (5,8 м $^{3}$ або $\left.26 \%\right)$. На тонких ступенях товщини (до $32 \mathrm{~cm}$ ) є тенденція до збільшення запасу, тоді як для найтовстіших дерев чіткої закономірності немає.

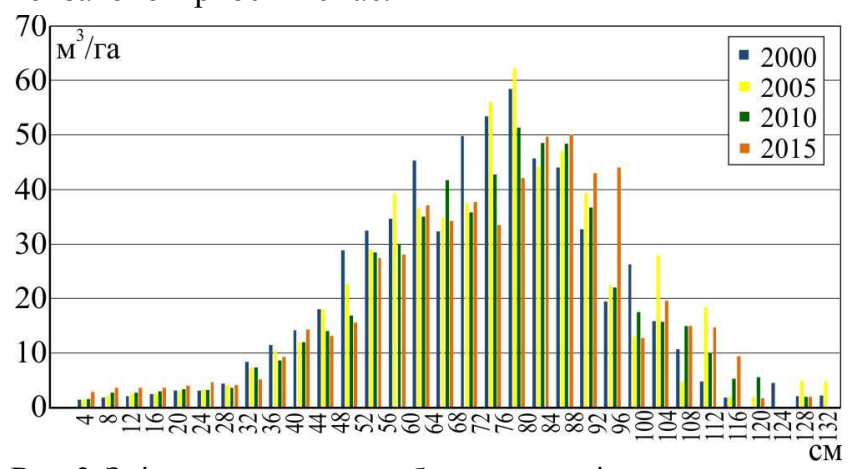

Рис. 2. Зміни запасу деревини букового пралісу за ступенями товщини

Вплив природних факторів спостерігаємо і на прикладі динаміки приросту за діаметром у різних ступенях товщини букового пралісу (рис. 3). Так, після вітровалу 2007 р. його значення збільшилося практично на всіх ступенях товщини, за винятком окремих ступенів великого діаметра - 80, 88, 100, 104 та 108 см. Найбільшим у відсотковому вимірі це зростання було на ступенях товщини 8, 48, 52 та 96 см і зазначимо, що в попередніх абзацах йшлося про найбільші втрати деревини саме на ступенях товщини 48 та 52 см. Тобто, вітер звалив значну кількість дерев саме 3 діаметром близько $52 \mathrm{~cm}$, а дерева такого самого діаметра, які залишилися рости, найістотніше збільшили свій приріст за діаметром, бо отримали достатньо простору завдяки поваленим деревам.

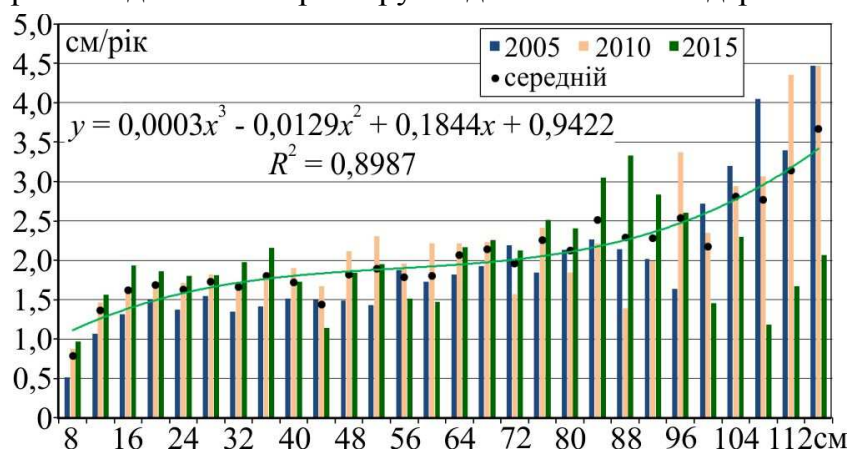

Рис. 3. Зміни приросту за діаметром за ступенями товщини

Показовим є і те, що в 2015 р. приріст дерев на тонких ступенях товщини продовжував зростати, тоді як у дерев 3 діаметра 40 см він істотно зменшився. Це означає, що тонкі дерева навіть на 8-й рік після вітровалу ще мають достатньо простору для свого росту, а товсті 
за ці роки вже закрили своїми кронами утворені вітром прогалини в наметі.

Розрахунок середнього для всіх чотирьох інвентаризацій приросту за діаметром дерев букового пралісу дає підстави констатувати про достатньо тісну поліноміальну (третього порядку) його залежність від діаметра (див. рис. 3). I якщо в дерев 3 діаметром 8 см цей приріст становить тільки $1 \mathrm{~cm} /$ рік, то у дерев 3 діаметром 60-80 см він дорівнює вже 2, а 3 діаметром більше $100 \mathrm{~cm}$ - перевищує $3 \mathrm{~cm} /$ рік. Також розрахунки свідчать, що існує тенденція до збільшення значень приросту за діаметром кожні 5 років, хоча і на цей час це зростання ще не перевищує для більшості ступенів товщини $10 \%$. Логічним поясненням цього є вже згадане зростання суми активних температур, тобто збільшення вегетаційного періоду.

Динаміку запасу мертвої деревини та кількості підросту букового пралісу з 2000 по 2015 рр. проаналізовано в іншій публікації (Shparyk et al., 2017).

Обговорення отриманих результатів дослідження. Те, що праліс $є$ екологічною системою, яка достатньо стійка до наявних у цій природній зоні абіотичних чинників, не підлягає сумніву і на прикладі стаціонарних досліджень букових пралісів Українських Карпат ця теза отримала ще одне підтвердження. Так, вітровал 2007 р., від якого на окремих ступенях товщини втрачено понад $25 \%$ дерев, не зруйнував праліс - за три роки після стихії повнота деревостану відновилася, а зменшення запасу деревини не перевищувало 10 \%. Це означає, що навіть сильний вплив вітру незначною мірою зменшив продуктивність пралісу через вилучення з процесу фотосинтезу певної кількості дерев першого ярусу. Але вітровал не зруйнував механізми саморегуляції пралісу, які вже за декілька років відновили його структуру, а також не змінив структуру букового пралісу. Схему реакції пралісу на вітровал представлено на рис. 4 (товщина стрілок визначає інтенсивність змін).

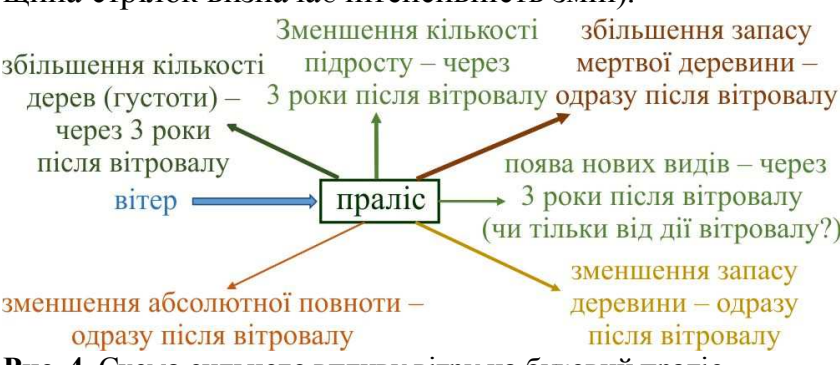

Рис. 4. Схема сильного впливу вітру на буковий праліс

При цьому вплив вітровалу на деревостан букового пралісу неоднозначний - 3 одного боку, було короткотермінове (1-2 вегетаційних сезони) зменшення кількості й запасу дерев, які залишилися рости, кількості підросту та абсолютної повноти, а $з$ іншого - довготермінове (через 3-5 вегетаційних сезони) збільшення густоти живих дерев і запасу мертвої деревини. Важливою $\epsilon$ часова фіксація змін пралісу під впливом вітровалів: зменшення повноти та запасу відбувається безпосередньо після вітровалу; збільшення запасу мертвої деревини відбувається в рік вітровалу, але переважно продовжується і ще декілька років, тому що пошкоджені дерева залишаються живими ще не один рік; зменшення кількості підросту проявляється не пізніше 2-3-х років і визначається переходом середнього і великого підросту у третій ярус (і насіннєвим роком); збільшення кількості дерев триває найдовше (до 10 років) завдяки наявності неоднорідного за висотою підросту та проблемності його переходу до складу деревостану. На загал, самовідновні функції пралісу за 8 років ще не повністю відновили ті показники, які були до вітровалу, але відповідна тенденція є чіткою і відхилення від норми за окремими показниками ще досягають до 60 \%. Це дає змогу спрогнозувати період повного відновлення пралісу після вітровалу в 20-25 років.

Висновки. Аналіз реакції букового пралісу на сильний вплив вітру в 2007 р. підтверджує гіпотезу про стійкість таких лісів до дії природних стихійних явищ. Навіть втрата на окремих ступенях товщини понад $25 \%$ дерев не призвела до критичних змін - за 3 роки повнота пралісу відновилася, а зменшення запасу не перевищувало $10 \%$. Основним елементом стійкості всієї екосистеми є висока життєвість бука лісового - кількість дерев та запас деревини саме цієї породи зазнали максимального впливу вітру Встановлено, що запас деревини букового пралісу в наступний рік після вітровалу зменшився майже на $60 \mathrm{~m}^{3} \cdot \mathrm{ra}^{-1}$ (на $10 \%$ ), через два роки це зменшення становило $7 \%$, а ще через п'ять тільки $4 \%$. Кількість живих дерев мала зворотну тенденцію - у 2010 р. збільшення становило $6 \%$ (і це на фоні втрати близько $10 \%$ дерев у 2007 р.), а в 2015 р. вже $59 \%$. Запас мертвої деревини теж зростає: у 2010 р. - на 41 \%, а в 2015 р. - ще на 6 \%. Кількість підросту під сильним впливом вітру зменшилася в 2010 р. на 19, а в 2015 р. - ще на 14 \%. Ці ідентифіковані кількісні зміни дали змогу розробити схему сильного впливу вітру на праліс.

\section{Перелік використаних джерел}

Commarmot, B., Brändli, U.-B., Hamor, F., \& Lavnyy, V. (2013). Inventory of the Largest Primeval Beech Forest in Europe. Birmensdorf, Lviv, Rakhiv.

Didukh, Y. P., Chornej, I. I., Budzhak, V. V., et al. (2016). Climatogenni zminy roslynnogo svitu Ukrainskykh Karpat [Climatogenic changes of the plant world of the Ukrainian Carpathians]. Chernivtsi: Druk ART. [In Ukrainian].

Hobi, M. L., Commarmot, B., \& Bugmann, H. (2015). Pattern and process in the largest primeval beech forest of Europe (Ukrainian Carpathians). Journal of Vegetation Science, 26, 323-336. https://doi.org/10.1111/jvs.12234

Kalutskyj, I. F., \& Olijnyk, V. S. (2007). Stykhijni yavyscha v girskolisovykh umovakh Ukrainy (vitrovaly, pavodky, erosiya gruntu) [Natural calamities in the mountain-forest conditions of the Ukrainian Carpathians (windfalls, floods, soil erosion)]. Lviv: Kamula. [In Ukrainian].

Korpel, S. (1995). Die Urwälder der Westkarpaten. Stuttgart, Jena. New York: Gustav Fischer.

Shparyk, Yu. S. (2016). Stale upravlinnia lisamy (na prykladi Ukrainskykh Karpat) [Sustainable forest management (on example of Ukrainian Carpathians)]. Ivano-Frankivsk: Terytorija druku. [In Ukrainian].

Shparyk, Yu. S., \& Viter, R. M. (2012). Vplyv vitru na stan derevostaniv ta lisivnychi zakhody dlya poperedzhennya vitrovaliv v Ukrainskykh Karpatax [Influence of wind on the forest stands and forestry actions to windfalls' prevention in the Ukrainian Carpathians]. Scientific Bulletin of UNFU, 22(15), 114-118. [In Ukrainian].

Shparyk, Yu. S., Commarmot, B., \& Berkela, Yu. Yu. (2010). Struktura bukovoho pralisu Ukrainskykh Karpat [Structure of the Ukrainian Carpathians beech virgin forest]. Snjatyn: Prutprynt. [In Ukrainian].

Shparyk, Yu. S., Viter, R. M., Berkela, Yu. Yu., Shparyk, V. Yu., Yanovska, I. M. (2017). Stan i dynamika bukovykh pralisiv Ugolskogo masyvu (na prykladi shvejtsarskoi proby) [Conditions and dynamics of beech virgin forests of the Ugolka massif (on the example of the Swiss plot)]. Proc.: The 10th Anniversary of the UNESCO 
World Heritage Property "Primeval Beech Forests of the Carpathians and Ancient Beech Forests of Germany ...", (pp. 386-391). Lviv: Rastr-7. [In Ukrainian].
Stojko, S. M. (2006). Pralisy yak ekologichni modeli renaturalizatsii vtorynnykh fitotsenoziv [Primary forests as ecological models of renaturalization of secondary phytocoenoses]. Ukrainskyj botanichnyj zhurnal, 63(3), 358-368. [In Ukrainian].

Ю. С. Шпарык, Р. М. Витер, В. Ю. Шпарык

Прикарпатский национальный университет им. Василия Стефаника, г. Ивано-Франковск, Украина

\section{ВЛИЯНИЕ ПРИРОДНЫХ ФАКТОРОВ НА ДИНАМИКУ БУКОВОГО (FAGUS SYLVATICA L.) ДЕВСТВЕННОГО ЛЕСА УКРАИНСКИХ КАРПАТ}

Международные исследования 15-летней динамики букового девственного леса проведены на 10-гектарном стационарном объекте в Угольском массиве Карпатского биосферного заповедника. Проанализировано влияние ветровала 2007 г. и потепления климата на структурные элементы экосистемы девственного леса. Выявлены достоверные изменения отдельных показателей девственного леса в результате сильного воздействия ветра: наибольшие колебания характерны для густоты деревьев - после потери 10 \% (в 2007 г.) уже в 2010 г. густота увеличилась на 6, а в 2015 г. - на 59 \%; существенно вырос и запас мертвой древесины (соответственно на 41 и $6 \%$ ); относительное уменьшение самым большим было для количества подроста (на 19 и 14 \%); уменьшение запаса древесины было уже меньше (на 7 и 4 \%); уменьшение суммы площадей поперечного сечения было не существенно (на 4 и 2 \%). Анализ реакции девственного леса на сильное воздействие ветра подтверждает гипотезу о максимальной устойчивости таких лесов к стихийным явлениям, а идентифицированные количественные изменения дали возможность разработать схему влияния ветровала на девственный лес. Дискуссионным остается вопрос увеличения прироста по диаметру под влиянием потепления климата - в 2010 и в 2015 гг. увеличение его было достоверным в девственном лесе для большинства ступеней толщины, но на динамику этого показателя повлиял также и ветровал посредством разрежения основного полога девственного леса.

Ключевые слова: ветровал; древостой; густота деревьев; запас древесины; мертвая древесина; подрост; потепление климата; прирост.

Yu. S. Shparyk, R. M. Viter, V. Yu. Shparyk Vasyl Stefanyk Precarpathian National University, Ivano-Frankivsk, Ukraine

\section{INFLUENCE OF NATURAL FACTORS ON THE DYNAMICS OF THE BEECH (FAGUS SYLVATICA L.) VIRGIN FOREST OF THE UKRAINIAN CARPATHIANS}

Virgin forest is supposed to be the most sustainable ecosystem to existing in this natural zone disasters. This publication analyses the impact of the 2007 windfall and climate warming on the structural elements of the virgin forest ecosystem. The object of our research was a 10 hectares massif $(200 \times 500 \mathrm{~m})$ of Common beech (Fagus sylvatica L.) virgin forest, which was divided on forty $(50 \times 50 \mathrm{~m}=0.25 \mathrm{ha})$ research plots. There were four inventories on all 40 plots in 2000, 2005, 2010 and 2015. Inventory methods were: measuring and mapping of all trees ( $\mathrm{DBH} \geq 6 \mathrm{~cm}$, living and dead); measuring of lying deadwood (D $\geq 8 \mathrm{~cm}$, length $\geq 2 \mathrm{~m})$ volume for degrees of decay; measuring of undergrowth (DBH $<6 \mathrm{~cm}, \mathrm{H} \geq 10 \mathrm{~cm}$ ) number for height groups. The dynamics of main parameters of the beech virgin forest after the catastrophic wind influence is not the same. The largest fluctuations are typical for the tree number - after the $10 \%$ loss of trees in 2007 the tree density increased in 2010 on $6 \%$, and in $2015-$ on $59 \%$. There is $9 \%$ annual increasing of tree number in the virgin forest during 8 years after windfall. The volume of a deadwood substantially increased on 41 and $6 \%$ respectively in 2010 and 2015. The undergrowth number substantially decreased - respectively on 19 and $14 \%$. The decrease in the wood volume of the virgin forest was already lower (respectively 7 and $4 \%$ ), while the decrease in the basal area was not significant (respectively 4 and $2 \%$ ). The diameter distribution in the beech virgin forest was constantly changing during these 15 years, but the type of the distribution remains declining, that is typically for uneven-age forests. In 2005 changes in the tree number within diameter classes fluctuated up to 25 per cent, and after windfall the magnitude of these fluctuations increased to $\pm 50 \%$. These quantitative changes made it possible to prepare a basic scheme for the influence of strong winds on the virgin forest and to set the time stages of this interaction. Diameter increment increasing defined in the beech virgin forest as a consequence of climate warming, but the windfall influence does not allow determining that clear.

Keywords: windfall; forest stand; tree density; wood volume; deadwood; undergrowth; climate warming; increment. 